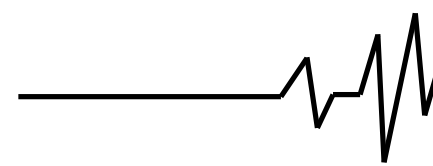

Shvets L.

Ph.D., Associate Professor

\section{Vinnytsia National Agrarian University}

Швець Л. В. к. т. н., доцент

\section{Вінницький національний аграрний університет}

УДК 621.3

DOI: 10.37128/2306-8744-2021-1-13

\title{
DEVELOPMENT OF DEVICE FOR RESTORATION OF PLACES FOR BEARINGS
}

Defects of case details include operation of openings under bearings within 0,2 - 0,4 $\mathrm{mm}$ on the party, operation of landing belts under sleeves. When restoring them, traditional methods are used: installation of repair bushings, application of polymer and electrolytic coatings, micron smelting, electrospark treatment, etc. Restored parts must have hardness and wear resistance with the parameters of the material of the reducing part (deviation 10 - 15\%), have sufficient adhesion to the base metal, corrosion resistance in a humid environment, provide maximum contact area with the conjugate part, no pores, slag, foreign inclusions.

The method of restoration must eliminate the thermal impact on the part and be cost-effective.

Polymer compositions are usually brittle, subject to breakage and leaching. Surfacing causes warping of the part, bleaching of cast iron, the formation of slag and pores in the deposited layer. The electrospark coating method does not provide sufficient contact area with the conjugate part.

The use of electrolytes for iron seats in some enterprises is aggressive, unstable, requires heating or the use of expensive thyristor power supplies, followed by machining, as the microhardness of precipitation reaches a large value depending on the composition of the electrolyte and process modes, have high internal voltage.

The proposed device for restoring the bearings simplifies the existing method and meets the technical requirements of manufacturers in terms of machining accuracy (ovality, taper, coaxiality and surface roughness), provides high productivity (2 times higher than the productivity of specialized machines horizontally). and low cost (60 times lower than the cost of specialized machines).

Key words: part, bearings, restoration.

Introduction. To change the design of the lower belt of the sleeve instead of two narrow rings use three: one flat wide, which is worn with tension on the sleeve at the top of the lower seat belt, and two narrow. To improve the disassembly of the sleeve from the cylinder block recessed recess under the ring in the sleeve.

When restoring the lower seat belts, the most widely used methods were: boring the lower seat belt to the repair size and installing the repair part - the sleeve; applying a polymer composition to the damaged surface and installing a gauge mandrel to form the correct geometric shape of the seat belt during curing of the composition.

The first method has disadvantages, the most significant of which - high complexity and high cost.
The second method is more economical. The surface restored by it provides reliable work of the engine within the repair period. However, when using it, there is often a violation of the geometric shape of the recovery surface (displacement of the upper and lower seat belts, mismatch after restoration, etc.), this is due to the fact that the device does not provide accurate installation of the gauge mandrel.

But a technological process of restoring seat belts was developed, which did not reveal any previous shortcomings. This is achieved by using specialized equipment that allows the polymer composition to restore the damaged surface to the nominal size.

As a base surface adopted the upper seat belt, which wears little during operation. A power 


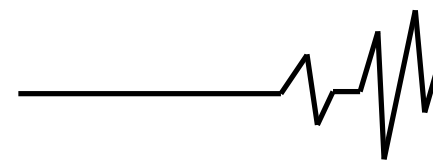

pneumatic cylinder is connected to the device to move the calibrating mandrel.

The average operating time of the engine without repair before leaving the allowable size of the upper seat belt is 324 thousand $\mathrm{km}$, which practically ensures the stability of the geometric shape of the seat belt during the two repair cycles.

The main material. Restoration of landing openings by installation of rings

Developed technology and equipment for the restoration of landing holes by installing rings on the epoxy warehouse. The ring (sleeve) is made in the device from a steel tape $0,5 \mathrm{~mm}$ thick. The manufacturing process consists of the following operations: cut the tape lengthwise and, if necessary, width, fold the ring for welding, while the tape is clamped around the precision mandrel, and spot welding of the ring [1]

The manufactured rings together with the mandrels are installed in the corresponding holes of the housing on the adhesive composition, orienting them on the inner surfaces relative to each other and the base surfaces of the housing in the device.

The rings have a final size in accordance with the requirements of the working drawing and are not subject to further processing. [2]

One of the ways to restore the landing holes in the body parts of machines, by installing turning sleeves on the glue, followed by unrolling them in the parts depending on the configuration and size on lathes and drilling machines.

The results of checking the cylinder blocks for tightness show that it is not always possible to obtain a tight coupling. Analysis of the engine, which was under supervision, says that the method of restoring the cylinder blocks by ringing with the use of sealing compounds, can not provide mass recovery of cylinder blocks with after repair life of not less than $80 \%$ of the new life.

The use as a sealing component of the compound KLT-30 brand B TU 28-103-262-75 allows you to easily and evenly apply a layer on the mating surfaces, easily remove excess, does not require compliance with certain temperatures, no time is spent on cooking the component. [3]

Self-vulcanizing compound KLT-30 is a liquid homogeneous mixture, which is packed in aluminum pipes of $0.05-0.3 \mathrm{~kg}$. It is intended for sealing of a surface and can keep the properties for a long time at work of engines in the conditions of vibration at a temperature from -60 to +300 degrees.

It takes a solid state under the action of moisture at a temperature of 0 to 40 degrees for 15 - 20 minutes. with the formation of a rubberlike material.

Checking the blocks restored by the ringing method using the sealing composition KLT

\section{№ 1 (100) \\ 2021 \\ Вібрації в техніці та технологіях}

- 30, for tightness gives $100 \%$ yield. The tightness of the coupling provides an $80 \%$ resource. rubbing

Restoration of openings by electrolytic

It would seem possible to use galvanic methods to restore the openings of body parts. After galvanic build-up "in size" by some metals (zinc, copper) no further machining is required. The equipment used for this purpose is simple, the coating process is stable.

But attempts to use galvanic baths to restore the openings of body parts were unsuccessful due to the many positions of operations, complex system of isolation of uncovered places, low build-up speeds, inability to visually observe the process, intensive growth of dendrites with increasing coating thickness.

Theoretical developments and research have revealed a number of methods known collectively as "electrolytic rubbing". Their essence is the deposition of the coating from the microwave, which is formed by an anode swab, which is moistened with electrolyte and pressed against the treatment surface of the recovery part. The tampon should fit snugly over the anode, and absorbent fabric is used as the material. In the process of electrical deposition, dendrites are removed and the sediment structure is partially compacted as a result of the anode pressure through the absorbent tissue. The disadvantage of this method is the sludge filling of the absorbent fabric, which leads to its introduction into the coating and the possibility of closing the circuit during local abrasion of the fabric.

More effective can be considered a method of deposition of the coating in a stream of electrolyte with mechanical activation of the surface, in which the removal of dendrites and compaction of the structure of sediments is carried out by devices (activators) mounted on a rotating anode. These include brushes made of nonconductive material, inert in this electrolyte, and bars fixed on an insulating base and made of materials whose microhardness

should be greater micro hardness of the deposited coating. The force of pressing the device to the treatment surface is chosen so that the structure is better compacted, it was possible to activate it and there was no growth of dendrites. However, this method is not yet sufficiently developed, the anode is difficult to manufacture.

Recently, in the repair industry, the method of deposition of the coating in the flow of electrolyte with simultaneous rotation of the anode has proved itself. At such restoration between a cathode and an anode which are covered with a cover from absorbing fabric, leave a backlash of $1,5-3 \mathrm{~mm}$ which is filled with a stream of electrolytes. The anode, as well as when rubbing, 


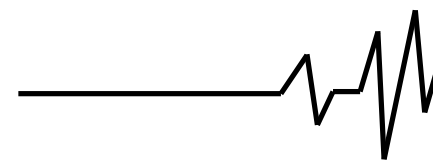

is given a rotational motion, but the speed increases by 2 - 5 times.

Reduction of dehydrite formation is achieved by increasing the flow rate of the electrolyte to $0.5-1.5 \mathrm{~m} / \mathrm{s}$ and gives it a rotational motion in the electrode space. [4]

Housing parts orient the moving parts of the unit during its operation. The defining features of the body part are: box shape, necessary for the formation of a closed working volume in order to accommodate the various mechanisms of the unit; rigid walls with ribbed tides, subjected to static and dynamic loads, in which smooth and threaded holes are made; the presence of long holes made in the assembled parts (including various materials), when the plane of the connection passes through the axis of the holes; the presence of butt planes; low roughness and high accuracy of the sizes, the form and an arrangement of the basic cylindrical and flat surfaces. The main defects of the body parts: cracks in the walls, cracks, curvature or wear of the joints, the destruction of the threads, deformation or wear of the guide and support elements, corrosion. Parts with cracks passing through the tides with precise holes are subject to rejection. The strength and tightness of the walls and the geometric accuracy of the elements are restored in the body parts. [2]

One of the most technologically complex body parts is the engine cylinder block, which is assembled with the bearings of the main bearings and the clutch housing during manufacturing operations. [5]

This assembly unit is not disassembled during operation and repair. The accuracy of the dimensions, shape and location of the conjugate surfaces and holes affects the durability of the repaired unit, so these surfaces must be accurately made. For example, the accuracy of the elements that determine the reliability of the crankshaft and camshaft bearings have the following values. Tolerances on the sizes of apertures correspond to the 5th or 6th quality of accuracy, total tolerance of roundness and a profile of longitudinal section of apertures - the 6th or 7th degree, parallelism of axes of apertures of bearings of a camshaft and apertures in radical support - 8th or 9th. - th degree, the coaxiality of the middle root support relative to the extreme 5 th or 6th degree. The roughness of the treated holes $\mathrm{Ra}=0.63 \mu \mathrm{m}$.

The scheme of technological process of restoration of case details is the following: preliminary mechanical processing of the damaged elements of a detail; production of DRD; welding (including those related to the consolidation of DRD) and surfacing; annealing to relieve internal stresses after welding; surface spraying; machining of welds; application of

\section{№ 1 (100) \\ 2021}

plastic coatings; installation of DRD, which are fixed by elastic forces, glue and pins; rough machining of joints and holes; cutting of threads of the nominal and repair sizes and installation of spiral threaded inserts; finishing of surfaces; surface treatment, cleaning; recovery control.

Machining at the beginning of the technological process is used to remove damaged elements, giving the restored surfaces the correct geometric shape, treatment of cracks, execution of stops and joints for the installation of DRD. Cracks are processed, for example, using a hand grinder IP-2002. A reinforced abrasive wheel is used as a tool. At the end of the cracks drill holes with a diameter of $3 \mathrm{~mm}$. Cracks in cast iron walls are welded with $\mathrm{PANCH}-11$ or -12 wire, or with artificial electrodes TsCH-ZA. The weld is applied in sections $20-25 \mathrm{~mm}$ long, which are forged. Welding work on parts made of aluminum alloy is performed using an installation for argon arc welding.

Welding and surfacing work is associated with the investment of heat in the material of the part and cause high internal stresses and associated deformations. Deformations of cast iron workpieces can be reduced by heating them before welding, holding at a temperature of $600^{\circ}$ $\mathrm{C}$ during welding and cooling together with the furnace. In place of broken tides of body parts made of aluminum alloy, weld DRD. Housing parts made of aluminum alloy, made by die casting, after welding must be heated and aged at a temperature of $180^{\circ} \mathrm{C}$ for 10 hours.

In the next part of the technological process is coated by spraying. Cracks and holes in the non-force walls of the part are sealed with pads using epoxy compositions based on resins ED16 or ED20. The main renewable elements of the body part are the guide elements and holes for bearings. The bearings of the main bearings in the cylinder block of the engine are a precise intermittent hole along the length, made both in the cylinder block and in the screw caps. The following methods of creating allowances on renewable surfaces have been tested in repair production: DRD installation; application of epoxy compositions; cold iron; gas-flame surfacing of brass; electric arc and plasma spraying.

Worn threads are restored by cutting threads of repair size, or welding holes with their subsequent drilling and cutting threads of nominal size, or screwing threaded inserts into a pre-cut thread of larger diameter. [6]

Worn holes for pins are unfolded to the repair size. Root supports and holes in the camshaft bushings are drilled in one place on a special machine. Then the root supports are honing. The lower plane of the cylinder block and two technological openings on it are used as technological bases. The cylinder block at the end 


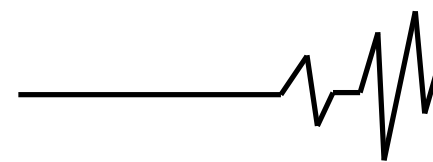

of the recovery is assembled with the clutch housing. The hole for the gearbox with the allowance for processing is drilled based on the 171 assembly unit on the finished root supports and one of the ends.

Control operations at the end of the restoration process consist of checking the purity of the part, its tightness, geometric dimensions of the elements and their relative position, surface roughness. The size of the holes is controlled by indicator gauges, and the roughness - by profilometers. The relative position of the surfaces is measured by indicator means. Particular attention is paid to the cleanliness and tightness of oil channels. The tightness of the walls of the assembly unit is checked on the stand. [7]

This method is used when restoring the seats of body parts on the installation.

Characteristics of the restoration part

The sockets of the main bearings of the crank mechanism of the internal combustion engine are included in the general complex casting of gray cast iron MF 18 and MF 21, with high casting and mechanical qualities. They belong to the fixed elements of the mechanism creating the engine case and providing rigid fastening of radical
№ 1 (100)

2021

bearings of sliding, thereby, forming steady work to all crank mechanism. The element of a radical support of the engine is a demountable cover of the radical bearing.

All surfaces of seats of radical supports of the engine are connected with basic necks of a cranked shaft through sliding bearings - radical inserts. The sockets under the liners have a surface roughness and must correspond to $\mathrm{Ra}=$ $1.25 \mathrm{mKm}$.

The main components of the projected device.

The device for restoring the bearings of the internal combustion engine bearings consists of a boring shaft 1 (Figure 1). On the boring shaft 1 are installed basic elements: the housing 2 with internal antifriction sleeves, which is based on the inner surfaces of the support housings through the gaskets in the form of inserts.

A conical reducer 5 is fixed to the coupling 6. The boring shaft 1 is rotated through the reducer 5 from the electric motor 11 . The electric motor 11 is connected to the reducer 5 by means of a coupling 10. The whole structure of the device is mounted on the frame 12 cylinders 3.

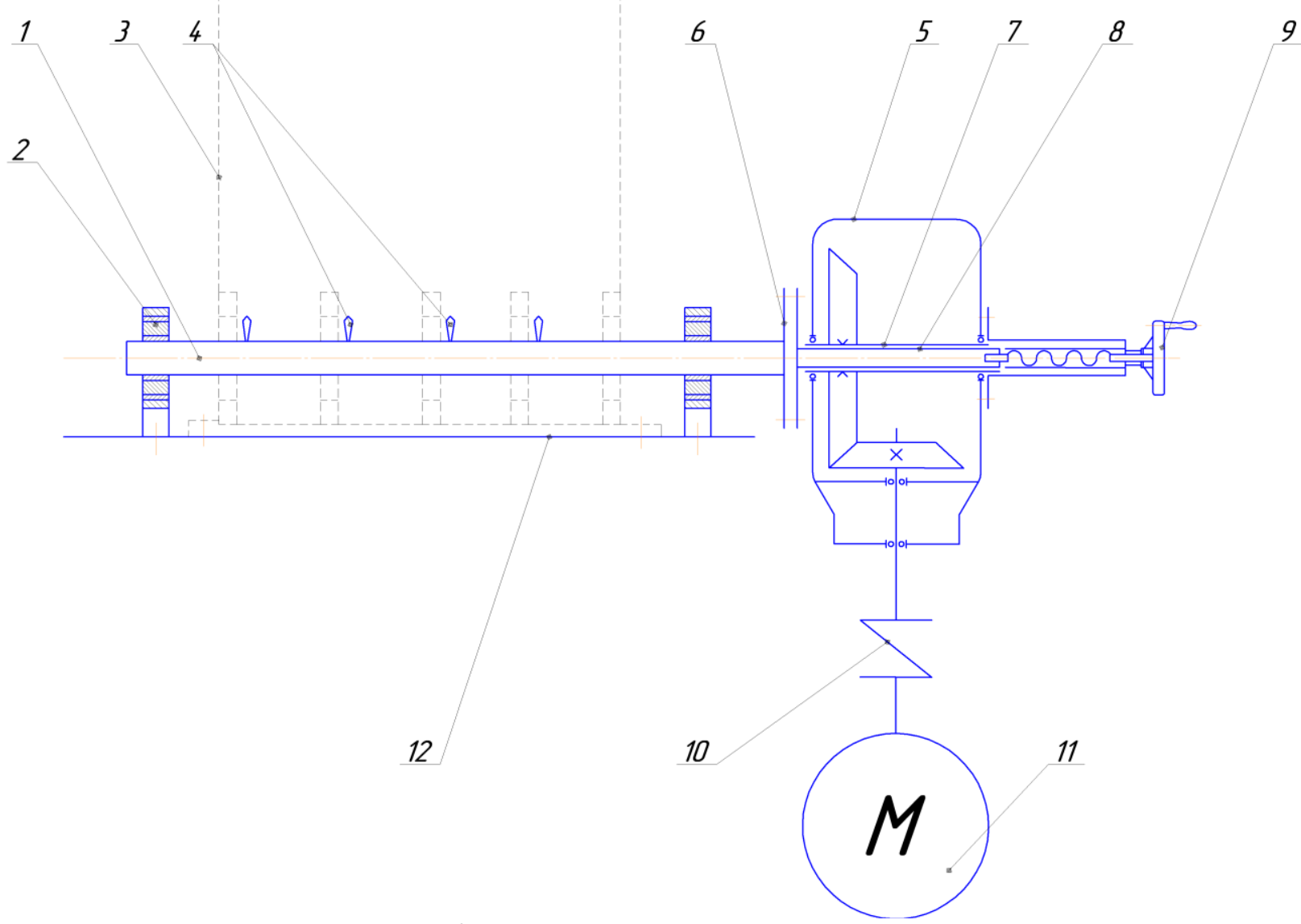

1 - the working shaft; 2 - the basic case; 3 - cylinder block; 4 - cutter;

5 - bevel reducer; 6 - coupling; 7 - a shaft of a gear wheel; 8 - internal splined shaft; 9 - feed mechanism; 10 - safety coupling; 11 - electric motor;

$$
12 \text { - bed. }
$$

Figure 1 is a kinematic diagram of the device 


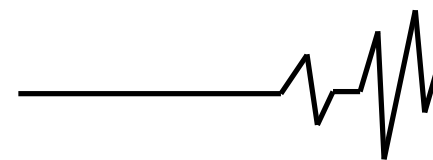

device

The principle of operation of the design

When boring seats, cutting tools 4 (Fig. 1) are fed (extended) to the required value. The operation of the boring device is carried out in the following order: the electric drive 11 through the coupling 10 and the reducer 5 rotates the boring shaft 1 based on the inserts in the support housings 2 . In addition to rotation due to the feed mechanism 9 the gear shaft 7 of the gearbox 5 . The boring shaft 1 moves along the bushings with built-in cutting tools 4 . The cutting tools 4 (cutters), rotating in accordance with the shaft 1 , bore the seats 3 .

After boring, it is necessary to remove the device from the bored unit and measure the diameters of the seats with an indicator gauge. Before and after boring of all places it is necessary to check up their alignment.

Duration of boring of one block of cylinders taking into account preparatory - finishing time no more than $1,5 \ldots 2$ hours.

The proposed device for restoring the bearings of the main bearings meets the technical requirements of manufacturers in terms of machining accuracy (ovality, taper, coaxiality and surface roughness), so it can be used for boring. The scope of the proposed device is wide: large repair companies, repair shops, small service stations and even individual garages. The wide scope of the proposed device is due to high productivity ( 2 times higher than the productivity of specialized machines of the horizontal boring group) and low cost (60 times lower than the cost of specialized machines)

\section{Conclusions}

The economic efficiency of the restoration of parts in comparison with their manufacture is determined by many factors. The cost of restoration of details in the conditions of modern car repair enterprises makes, depending on a design and technological features of details and character of their defects, $10-50 \%$ of cost of new details. When restoring parts, material costs are significantly reduced. If the cost of materials and production of blanks in the manufacture of cars is $70-75 \%$ of their cost, then in the restoration of parts - $1-12 \%$ depending on the method of restoration. The costs associated with the treatment of parts are significantly reduced, as only surfaces with wear or mechanical damage are treated. Restoration of parts reduces the need for production of spare parts and reduces the cost of their purchase, which is $40-60 \%$ of the cost of overhauling cars. Restoration of parts provides significant savings of raw materials, energy and labor.

\section{№ 1 (100) \\ 2021 \\ Вібрації в техніці та технологіях}

1. Budyak RV, Posvyatenko EK, Shvets LV, Zhuchenko GA (2020) Construction materials and technologies: Vinnytsia: VNAU, 2020. 240 p. [in Ukrainian].

2. Kalchenko VI, Kalchenko VV, Venzhega VI (2013) Restoration of car parts. Chernihiv: ChNTU, 2013. 192p. [in Ukrainian].

3. Shvets LV, Paladiychuk YB, Trukhanskaya OO (2019)Technical service in the agro-industrial complex. Tom I. Textbook. VNAU, 2019. [in Ukrainian].

4. Posviatenko E., Budyak R.,Shvets L. (2018) Influence of a material and the technological factors on improvement of operating properties of machine parts by reliefs and film coatings. Eastern-European Journal of Enterprise Technologies. 2018. № 5/12 (95). P. 48-56. [in English]

5. Pulupec M., Shvets L. (2019) Characteristics and thermomechanical modes of aluminum alloys hot deformation. Current Problems of Transport: Proceedings of the 1st International Scientific Conference. Ternopil Ivan Puluj National Technical University and Scientific Publishing House «SciView». Ternopil, 2019. pp 195-204. [in English]

6. Truhanska O.O. (2020) Promising directions of technology of restoration of details of cars. Vibrations in engineering and technology 2020. №3 (98). P.104-110. [in English]

7. Truhanska O.O. (2020) Technological methods of increasing wear resistance and durability of details. Machinery, energy, transport of agro-industrial complex. 2020. № 4 (111). C.109-115. [in English]

\section{РОЗРОБКА ПРИСТРОЮ ДЛЯ ВІДНОВЛЕННЯ ГНІЗД ПІД КОРІННІ ПІДШИПНИКИ}

До дефектів корпусних деталей відносять спрацювання отворів під підшипники в межах 0,2 - 0,4 мм на сторону, спрацювання посадочних поясків під гільзи. При відновленні їх, застосовують традиційні способи: встановлення ремонтних втулок, нанесення полімерних $i$ електролітичних покрить, мікронаплавку, електроіскровий обробіток та ін. Відновленні деталі повинні мати твердість i зносостійкість 3 параметрами матеріалу відновлювальної деталі (відхилення 10 - 15\%), володіти достатньою адгезійністю 3 основним металом, корозійною стійкістю в вологому середовищі, забезпечувати максимальну площу контакту з спряженою деталлю, не мати пор, шлаку, по сторонніх включень.

$$
\text { Метод відновлення повинен }
$$

виключити термічний вплив на деталь і бути економічно вигідним. 


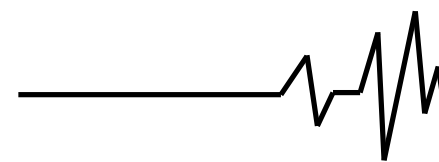

Полімерні композиції, як правило, крихкі, які підлягають обломам і вимиванню. Наплавлення викликає короблення деталі, відбілювання чавуна, утворення шлаків і пор в наплавленому шарі. Електроіскровий метод нанесення покриття не забезпечує достатньої площі контакту із спряженою деталлю.

Застосування на деяких підприємствах електролітів для залізнення посадочних місць агресивні, нестабільні в роботі, вимагають підігріву або застосування дорогих тиристорних джерел живлення із наступною механічною обробкою, так як мікротвердість осадків досягає великої величини в залежності від складу електроліту i режимів процесу, володіють великою внутрішньою напругою.

Запропонований пристрій для відновлення посадочних місць корінних підшипників спрощуе існуючий метод $і$ відповідає технічним вимогам заводіввиготівників по точності обробки (по овальності, конусності, співвісності $і$ шорсткості поверхні), забезпечує високу продуктивність (у 2 рази вище за продуктивність спеціалізованих верстатів горизонтально-розточувальної групи) i низькою вартістю (у 60 разів нижче за вартість спеціалізованих верстатів). відновлення.

Ключові слова: деталь, підшипники,

\section{РАЗРАБОТКА ПРИСПОСОБЛЕНИЯ ДЛЯ ВОССТАНОВЛЕНИЯ МЕСТ ПОД ПОСАДКУ КОРЕННЫХ ПОДШИПНИКОВ}

К дефректам корпусных деталей относят срабатывание отверстий под подшипники в пределах 0,2 - 0,4 мм на сторону, износ посадочных поясков под гильзы. При восстановлении их применяют традиционные способы: установка ремонтных втулок, нанесение полимерных и электролитических покрытий, микронаплавку, электроискровой обработку и др. Восстановлении детали должны иметь

\section{Вібрації в техніці та технологіях}

твердость и износостойкость $~ с$ параметрами материала восстановительной детали (отклонение 10 - 15\%), обладать достаточной адгезийнистю с основным металлом, коррозионной стойкостью во влажной среде, обеспечивать максимальную площадь контакта с сопряженной деталью, не иметь пор, шлака и т.д.

Метод восстановления должен исключить термическое воздействие на деталь и быть экономически выгодным.

Полимерные композиции, как правило, хрупкие, подлежащих облом и вымыванию. Наплавки вызывает деформации детали, отбеливание чугуна, образование шлаков и пор в наплавленном слое. Электроискровой метод нанесения покрытия не обеспечивает достаточной площади контакта с сопряженной деталью.

Применение на некоторых предприятиях электролитов для железнения посадочных мест агрессивные, нестабильные в работе, требуют подогрева или применения дорогих тиристорных источников питания с последующей механической обработкой, так как микротвердость осадков достигает большой величины в зависимости от состава электролита и режимов процесса, обладают большим внутренним напряжением.

Предлагаемое устройство для восстановления посадочных мест коренных подшипников упрощает существующий метод и удовлетворяет техническим требованиям заводов-изготовителей по точности обработки (по овальности, конусности, соосности и шероховатости поверхности), обеспечивает высокую производительность (в 2 раза выше производительность специализированных станков горизонтально-расточной группы) $u$ низкой стоимости (в 60 раз ниже стоимости специализированных станков).

Ключевые слова:

подшипники, восстановление.

\section{Відомості про автора}

Швець Людмила Василівна - кандидат технічних наук, доцент кафредри агроінженерії і технічного сервісу Вінницького національного аграрного університету (ВНАУ, вул. Сонячна, 3, м. Вінниця, Україна, 21008, e-mail: shlv0505@i.ua).

Швец Людмила Васильевна - кандидат технических наук, доцент кафедры агроинженерии и технического сервиса Винницкого национального аграрного университета (ВНАУ, ул. Солнечная, 3 , г. Винница, Украина, 21008, e-mail: shlv0505@i.ua).

Shvets Ludmila - PhD, Associate Professor, Department of Agricultural Engineering and Technical Service Vinnytsia National Agrarian University (Sunny str., 3, Vinnytsia, Ukraine, 21008, shlv0505@i.ua). 